\title{
WEB-BASED LEARNING MEDIA USING HYPERTEXT MARKUP LANGUAGE AS COURSE MATERIALS
}

\author{
Hiskia Kamang Manggopa, Christine Takarina Meitty Manoppo, Peggy Veronica Togas, \\ Alfrina Mewengkang, and Johan Reimon Batmetan \\ Study Program of Information and Communication Technology Education, Faculty of Engineering, \\ Manado State University, Manado, Indonesia \\ Email: hiskiamanggopa@unima.ac.id
}

\begin{abstract}
Recently, numerous web-based applications with attractive user interface, brand-new and advanced features, and friendly operation are rapidly developed and widely used, particularly in education context. This study aims to produce web-based learning media that are feasible for delivering materials of web programming subject. The course material of this subject is Hypertext Markup Language (HTML).This study is located at Manado State University, at the study program of information and communication technology. The method of this study employs the research and development model. The data were obtained by four questionnaires, including (1) the feasibility testing by the lecturer, (2) the media expert feasibility testing, (3) the materials expert feasibility testing, and (4) the students' feasibility testing. Based on the experimental results, it can be stated that the developed web learning is considered useful. It can be concluded that the web-based learning media is feasible to be used and effectively improve the quality of learning.
\end{abstract}

Keywords: hypertext markup language, web programming

\section{INTRODUCTION}

The development of industrial science and technology is currently at the peak of the global economy which brings an impact on the transition from the digital to the global information era. In line with this, Waras [1] stated that there will be more and more jobs will be taken over by machines and robots in the future. The industrial system is also more efficient because of computerization era and the role of information and communication technology. There are quite a number of information and communication technology devices that are available and can be used as learning media including films, television, diagrams, textbooks, learning modules, audio learning, video learning, computer-based learning, and Web or internet-based learning. Due to of these, the rapid progress of information technology contributes greatly for reducing space limitations and time constraints in the learning process. Hidayat et al. [2] stated that technology now allows students to interact with teachers and others without having to meet face-to-face, by using elearning media.

Web-based programs are increasingly being used by educational institutions. The web is the collection of pages or files that are interconnected and interrelated with each other. Due to internet facility, the web can connects documents both locally and remotely. Web-based learning has increasingly been developed by many scholars because it is very useful for students and teachers. Nowadays, most colleges have web-based learning system to manage a large number of course resources during higher education process [3]. The development of web learning is also one of the first steps to anticipate and face the wave of changes due to the industrial revolution 
4.0 era where the role of information technology is one of the dominant factors in conducting digital supply chains. The achievement of this supply chain can be obtained by an integration manner that is very dependent on integrating of technological elements to build it. Web competencies are required to develop education producing graduates who are ready to enter the industrial revolution era 4.0. Therefore, the creation and development of programs related to understanding and using internet technology through web learning is an urgent need to be realized soon.

Cook, et al. [4] studied that the role of web-based learning in health professional education has rapidly grown and almost all medical schools in the United States and Canada have currently used online materials. By this growth, there is an urgent need to understand how to design and implement learning effectively. The results of webbased education activities will vary depending on the intervention, interaction with the topic, the characteristics of students and the specific learning context. In designing the learning web, it is necessary to pay attention to media formats such as tutorial and online discussions. While instructional methods or learning techniques can be carried out with discussions, case studies, simulations, interactive models, and multimedia percentages. Many web-based educational applications are expected to be used by different user groups without the help of teaching staf [5]. Hence, there is a need for a system that can adapt to users with very different backgrounds, initial knowledge of the subject, and learning objectives.

The effectiveness of learning processes and outcomes can be improved through the use of web-based learning.
Wijaya [6] stated that learning using webbased method to improve learning outcomes is higher than using conventional methods. Nugroho [7] added that students' learning outcomes show significant value. Therefore, the development of web-based learning can improve learning achievement. Pu-Shih [8] concluded that there is a positive relationship between the use of web learning and students' involvement and learning outcomes. Jung, et al. [9] revealed that the students' learning experience using webbased method brings a positive attitude change.

In fact, some educational institutions have not utilized web-based to improve the quality of learning. Its problem becomes one of the main points and is very urgent to find ways to overcome. Based on observations, experiences, and observations at the Information and Communication Technology Education Study Program, Faculty of Engineering, Manado State University, it was found that the process and results of learning in Web Programming course, specifically Hyper Text Markup Language (HTML) materials did not achieve the expected results. HTML is the foundation subject of webpage programming language. It appears as a new standard of progress and development of the internet.

The lack of optimal process and results of learning HTML material is caused by some factors: the tendency of learning which is mainly in the form of lecturing, presentation, practice and practice of problems and lack of applying interactive learning, lack of balanced learning time and density of materials so that additional learning systems are needed for students to understand the materials.

The challenges for not having optimal process and learning outcomes, can be seen in the following findings: (a) students did 
not use teaching materials, media, and online learning resources as learning media, (b) the students were passive and the Web programming is very difficult, time consuming, and boring. This causes student motivation and learning achievement low, (e) teaching materials and strategies that can trigger the ideas to develop programs are very limited and not varied, so that the density of material and time constraints make it difficult for students to learn. The problems faced by these students need to be overcome so that learning becomes more effective. If students get learning convenience, it will increase motivation to learn. Correspondingly, Syarif [10] stated that if learning motivation increases, then all learning activities will be responded well, giving rise to students' curiosity, all learning activities will be directed towards studying learning materials with the aim of getting high learning outcomes".

Observing the conditions of the implementation of Web Programming that seems routine and as it is, it requires a study that aims to produce an effective learning system in order to achieve students' competence. The success of organizing lectures on Web Programming materials and its objectives can be achieved optimally, one of them is by implementing learning models that encompass comprehensive planning, implementation, and assessment of lecturers by optimizing the use of web learning. The implementation model of learning is expected to realize the learning administrator that can reflect the situation of the world of work at the same time in order to improve the learning quality of students. Hence, they are ready to enter, face challenges and master the fourth industrial revolution. The main problems can be formulated as follows: (1) How to develop a web learning to teach HTML materials courses. (2) Is the developed web learning appropriate to be used to teach Web Programming, and (3) Is the developed web learning effective in improving the learning outcomes. This study aims to produce a Web learning application and to evaluate the product's effectiveness in improving learning outcomes

\section{METHOD}

This study used a research and development model. The product of this study is a web learning to teach HTML materials. The research and development model used is a conceptual model adapted from the Borg \& Gall [11]. The steps of the study have several stages, including needs analysis, instructional design, product development, product evaluation, formative evaluation, and sumative evaluation. The formative evaluation consisted of individual evaluations, small group evaluations, and field evaluations. The sumative evaluations were carried out after the program has been formally evaluated.

The first stage examines the problems related to the preparation and procedure of students taking lectures on HTML materials, number of course participants, use of instructional media, availability of computer laboratories, internet networks, practicum rooms, readiness of lecturers, and students who participate in this research and evaluation. The next step examines the components that must be included and designs alternative solutions to be a complete and integrated system. Realization is carried out by compiling the stages of implementation, expert validation, evaluation and revision and implementation

The second stage develops the learning design. A learning syllabus is developed as the basis for developing the 
web learning. The development of this syllabus consists of eight steps, including (1) determining competency standards, (2) determining basic competencies, (3) conducting learning analysis, (4) formulating indicators, (5) developing assessment instruments, (6) developing learning materials, (7) developing learning strategies, and (8) designing evaluations.

The third stage produces media in the form of web learning to teach HTML. Web learning development is carried out using the multimedia development life cycle method proposed by Luther [12], which consists of 6 stages, including concept, design, material collection, manufacturing, testing, and distribution.

The fourth stage is formative evaluation consisting of validation, trial and product revision. The web learning is validated by material experts covering aspects of content and presentation. Validation by media experts includes aspects of software engineering, learning and visual communication. The trial is carried out through individual trials, small group trials, field trials followed by data analysis, and product revisions based on the results of the trials. The procedure for developing web learning is outlined on Figure 1

The fifth stage is summative evaluation to determine the effectiveness or function of the final product or program in improving the quality of learning in the form of increasing achievement of learning outcomes. The validation involved 2 material experts and 2 media experts. At the individual trial stage, the trial subjects were 4 people. In the small group trials, 12 people were tested, and the field trial involved 30 people. The data obtained from trials were in the form of qualitative and qualitative data. Qualitative data were in the form of suggestions or entries from media experts, materials experts, and students that were used to improve the product. Quantitative data obtained through questionnaires with a Likert scale were analyzed using descriptive statistics, while the assessment of the quality is based on the results of the conversion of scores with a scale of five [13]. The effectiveness of learning outcome can be seen from the test results. Figure 1 illustrates the product development process.

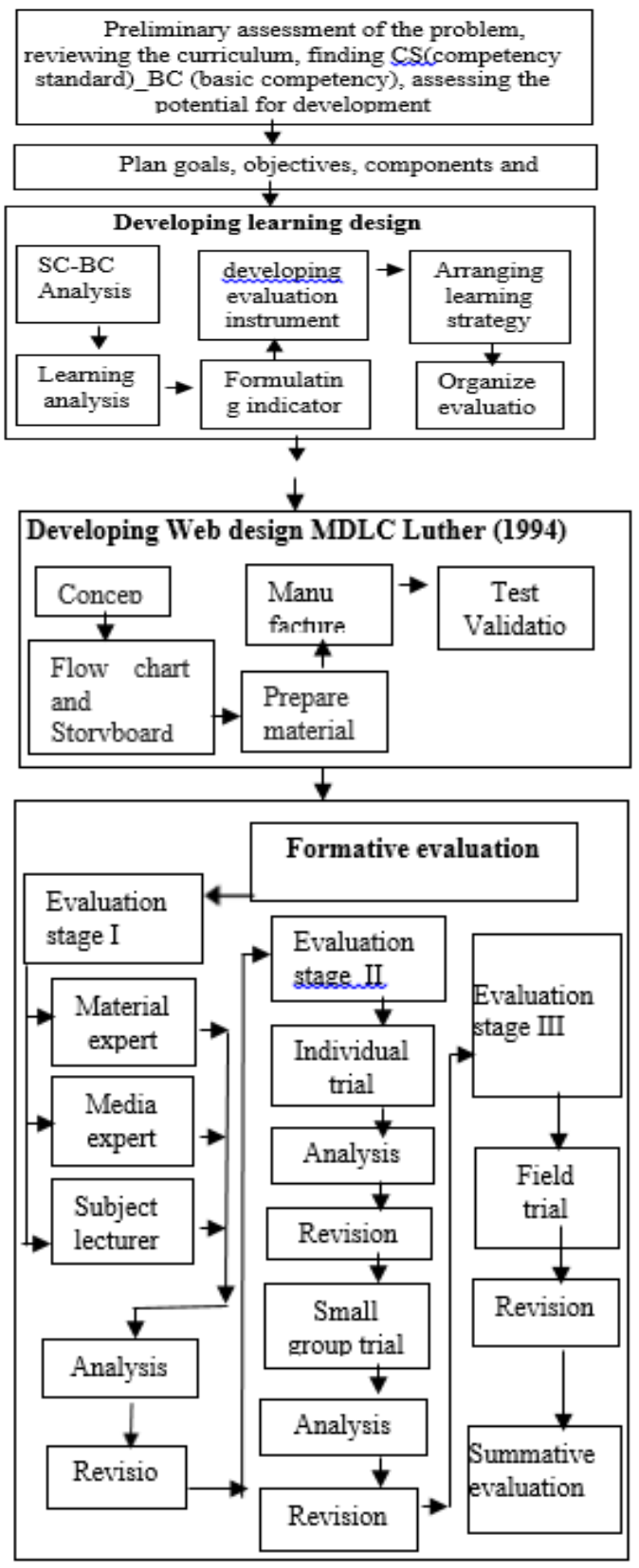

Figure 1. The Product Development Process 


\section{RESULTS AND DISCUSSION}

The output of this study is the developed learning website that can be used to teach HTML as well as a source of learning references for students. This website learning has menu and links that make it easier for students to access materials from the website, or materials from outside the learning website. In addition, a user guide is also provided to help students or users in learning and using the materials on the website. The main menu of learning website consists of eight parts, including home, profile, material, sending assignments, articles, program installation, evaluation, and login.

The media expert's assessment of the quality of learning web products in terms of software engineering shows a score of 3.39 and it can be considered as a good category. The other, namely the learning aspect also achieve high score of 3.44 and it can be categorized as excellent category. Lecturer assessment results on the quality of learning web products in terms of software engineering shows a score of 3.44 and it can be considered as a good category. The learning aspect had the score of 3.50 which it is also categorized as very good. It can be said that the results are considered good and effective to be used.

Furthermore, the results of the quality assessment of the web learning products in individual trials showed that the scores for the aspects of utilization, visual communication and software engineering, were $3.46,2.91$, and 3.25 , respectively. Those three scores are in a good category. The score of the test results for all subsubject matter had an average score of 23.75 (2.63). The students who completed this test are 4 students or $100 \%$. It is said that the product can improve learning achievement effectively.

The results of the quality assessment in small group trials showed that the aspect of utilization obtained the score of 3.00 or in a good category. The aspects of visual communication and software engineering obtained the scores of 3.09 and 3.44. They can be categorized as good and very good, respectively. The score of the test results for all sub-subject matter had an average score of 23.92 (2.66). The students who did not complete was 1 student or $8.34 \%$ while students who completed were 11 students or $91.66 \%$. This confirmed that the product can improve the students' learning achievement effectively.

Besides from the results of the quality assessment in the field trials, it was revealed that the utilization aspect obtained scored value 3.54 or a very good category. The visual communication and software engineering aspects were 3.09 and 3.33 and they are categorized as good and very good category. The value of the test results for all sub-subject matter with an average score of 23.78 (2.63), students who did not complete was $10.52 \%$ while students who completed was $89.48 \%$. This shows that the developed web learning can improve students' achievement

Based on the results, there are several considerations that will be discussed further. The results of media expert evaluations of learning websites in terms of software engineering are categorized as good, while the assessment of learning aspects shows this learning website is in the category of very good. These results explain that the learning website has fulfilled the basic criteria and is feasible to be used to teach HTML, without having to make a thorough revision. Suggestions from media experts 
are to eliminate duplication of material topics in the links listed, as well as the need for additional reference sources for each sub-material, while suggestions from lecturers in the subject include the importance of adding or completing the material provided on the website, attaching complete material in pdf format, and the importance of separating the contents of the exercise based on sub-material (from the subject of learning). These suggestions are used as references in revising learning websites. In general, the results of evaluations from media experts and lecturers showed that the developed learning website has been adequately developed and is suitable for use in the learning process.

In general, the implementation of the individual trials did not experience significant obstacles. Accessing websites using different operators did not have serious problems, including ease of access using different devices, such as different mobile phones, laptops or computers. This means that in terms of learning implementation websites are declared easy to use with different tools. The results of individual trials on learning websites show good results on the aspect of visual communication and software engineering, and very good category on aspects of utilization. This means that learning website development results have shown good ability to be used to teach HTML. Minor improvements on the results of this test are in the form of grammar spelling, punctuation, and optimization of instructions to make it easier to be understood. Based on the assessment of individual trials, the learning website of the development results is considered good and feasible. The average score's from 4 student tests or participants showed the value of 23.75 (2.63). Furthermore, these findings underlie the optimism that HTML teaching using learning websites is effective in improving students' achievement.

The results of development and improvement from the previous stage then were tested on a small group of 12 students. Reviewing the results of previous trials shows that not all students succeed in understanding the procedures for using the developed website. Therefore, at this stage, before the test, the participants receive the explanation about the accessing procedure of the learning website, so that the participants are able to carry out the tasks given effectively and efficiently. The results of small group trials showed that the aspects of utilization and visual communication are rated in good categories, while software engineering is rated in a very good category. Generally, the developed learning website can be used and feasible to teach HTML without the need to revise it thoroughly. The average test scores of 12 trial participants were 23.92 (2.66), with a completion rate of $91.66 \%$. These results indicated that the developed website learning has a positive contribution to students' learning achievement.

The field trial involved 19 students, who received a detailed explanation of operational procedures before accessing the learning website. This phase can be referred as a product test, which produces data on the level of feasibility and effectiveness of learning web that have been developed. The results of field trials or the results of product test studies show good assessment on the aspects of visual communication, and are very good on the aspects of web utilization and software engineering. These results explain that the developed learning website is effective and feasible to be used to teach HTML without a thorough revision. The effort to improve product quality from the 
results of this test is to add a choice of evaluation sub-menu and send task features. The results of the HTML subject test for 30 students showed an average of 23.78 (2.63), and the level of completion by students was $89.48 \%$. These results reiterate that the developed learning website has a positive contribution to student learning achievement

Research and development has been carried out. Learning web products to teach HTML material have been developed in accordance to procedures and are suitable for use in learning, products can improve learning outcomes. Several other researchers revealed that students who study in the classroom using web learning actually feel that they are able to contribute than students who study in traditional classes. Lee \& Tsai [14] stated that students in web-based learning provide better learning outcomes compared to traditional learning. Wijaya [6] stated that learning using web-based to improve learning outcomes is higher than increasing learning outcomes taught using conventional methods. Nugroho [7] concluded that students' learning outcomes indicate significant value, so that the development of web-based learning can improve learning achievement. Pu-Shih et al. [8] concluded that there was a positive relationship between the use of web learning and students' involvement and learning outcomes. The results of research carried out by Jung, et al. [9] revealed that the learning experience obtained by students brings a positive attitude change in relation to the use of the Web in learning. Web-based learning can facilitate lecturers in transferring materials taught to students, train students' abilities and activeness, because students can learn on their own whenever and wherever they are. [15]
From the results of this study it can be concluded that there is a positive relationship between the use of web learning with students' involvement and learning outcomes, the learning experience experienced by students brings changes in positive attitudes, encourages the students to contribute more, provides better learning outcomes, and improves learning achievement.

\section{CONCLUSION}

The web-based learning development procedure for teaching HTML courses on web programming was carried out through five stages: needs analysis, developing learning design, producing learning multimedia, conducting formative evaluation, and conducting summative evaluation. The basic competency developed through the materials in the web learning includes HTML sub menus containing: Competency Standards, Learning Outcomes Indicators and Guidelines. Material: Understanding HTML, HTML Format Text, HTML List Sequence, HTML Table, HTML Image, HTML Hyperlink, HTML Form, Complete Material, Tasks, Evaluation and Referrals. Secondly, the developed learning web is appropriate to be used to teach the HTML materials for programming. It was proven to be effective in improving learning outcomes of HTML materials in Web Programming courses. It is suggested to prepare supporting facilities and student needs. The use of web learning should apply the recitation method with group learning which is considered better than individual learning. It is also suggested to follow the instructions on how to study materials prepared as study companions 


\section{REFERENCES}

[1] K. Waras, "Inovasi Pembelajaran Teknik Dan Vokasi: Antisipasi terhadap Perubahan Paradigma Belajar," Malang, 2017.

[2] N. Hidayat, S. Hadi, A. Basith, and S. Suwandi, "Developing E-Learning Media with the Contiguity Principle for the Subject of Autocad," $J$. Pendidik. Teknol. dan Kejuru., vol. 24, no. 1, pp. 72-82, Apr. 2018.

[3] J. Peng, D. Jiang, and X. Zhang, "Design and Implement a Knowledge Management System to Support Web-Based Learning in Higher Education," Procedia Comput. Sci., vol. 22, pp. 95-103, 2013.

[4] D. A. Cook, S. Garside, A. J. Levinson, D. M. Dupras, and V. M. Montori, "What Do We Mean By Web- Based Learning? A Systematic Review of the Variability of Interventions," Med. Educ., vol. 44, no. 8, pp. 765-774, 2010.

[5] P. Brusilovsky, J. Eklund, and E. Schwarz, "Web-Based Education for All: A Tool for Development Adaptive Courseware," J. Comput. Networks ISDN Syst., vol. 30, no. 17, pp. 291-300, 1998.

[6] M. Wijaya, "Pengembangan Model Pembelajaran E-Learning berbasis Web Dengan Prinsip E-Pedagogy dalam Meningkatkan Hasil Belajar," J. Pendidik. Penabur, vol. 11, no. 19, pp. 20-27, 2012.

[7] N. Rinaldi Dwi, "Pengembangan Media Pembelajaran Berbasis Website Pada Mata Pelajaran Programmable Logic Controller," Universitas Negeri Yogyakarta, 2013.

[8] P.-S. D. Chen, A. D. Lambert, and K. R. Guidry, "The Impact of WebBased Learning Technology on College Student Engagement," Comput. Educ., vol. 54, no. 4, pp. 1222-1232, May 2010.
[9] I. Jung, S. Choi, C. Lim, and J. Leem, "Effects of Different Types of Interaction on Learning Achievement, Satisfaction and Participation in Web-Based Instruction," J. Innov. Educ. Teach. Int., vol. 39, no. 2, pp. 153-162, 2010.

[10] I. Syarif, "Pengaruh Model Blended Learning terhadap Motivasi dan Prestasi Belajar Siswa SMK," $J$. Pendidik. Vokasi, vol. 2, no. 2, pp. 234-249, 2012.

[11] W. R. Borg and M. D. Gall, Educational Research, An Introduction Fifth Edition. New York: Longman, 1983.

[12] Luther, Arc C. Authoring Interactive Multimedia. Boston: AP Professional, 1994.

[13] Sukardjo, Evaluasi Pembelajaran. Buku Pegangan Kuliah. Yogyakarta: Universitas Negeri Yogyakarta, 2010.

[14] S. W. Y. Lee and C. C. Tsai, "Student Perceptions of Colaboration, Self Regulated Learning, and Information Seeking in the Context of Internet-based Learning and Traditional Learning," Comput. Hum. Behav., vol. 27, pp. 905-914, 2011.

[15] D. G. H. Divayana, P. W. A. Suyasa, and N. Sugihartini, "Pengembangan Media Pembelajaran Berbasis Web Untuk Matakuliah Kurikulum dan Pengajaran di Jurusan Pendidikan Teknik Informatika Universitas Pendidikan Ganesha," J. Nas. Pendidik. Tek. Inform., vol. 5, no. 3, pp. 149-157, 2016. 